\title{
IMPROVING CONSTRUCTION PROJECT PERFORMANCE IN DEVELOPING COUNTRIES:
}

DOI:

10.14455/ISEC.res.2020.7(1).CON-14

\section{Document Version}

Final published version

Link to publication record in Manchester Research Explorer

\section{Citation for published version (APA):}

Adekunle, S. A., Aigbavboa, C., \& Ejohwomu, O. (2020). IMPROVING CONSTRUCTION PROJECT

PERFORMANCE IN DEVELOPING COUNTRIES: CONTRACTOR APPROACH. In Y. Vacanas, C. Danezis, A. Singh, \& S. Yazdani (Eds.), Proceedings of International Structural Engineering and Construction https://doi.org/10.14455/ISEC.res.2020.7(1).CON-14

Published in:

Proceedings of International Structural Engineering and Construction

\section{Citing this paper}

Please note that where the full-text provided on Manchester Research Explorer is the Author Accepted Manuscript or Proof version this may differ from the final Published version. If citing, it is advised that you check and use the publisher's definitive version.

\section{General rights}

Copyright and moral rights for the publications made accessible in the Research Explorer are retained by the authors and/or other copyright owners and it is a condition of accessing publications that users recognise and abide by the legal requirements associated with these rights.

\section{Takedown policy}

If you believe that this document breaches copyright please refer to the University of Manchester's Takedown Procedures [http://man.ac.uk/04Y6Bo] or contact uml.scholarlycommunications@manchester.ac.uk providing relevant details, so we can investigate your claim.

\section{OPEN ACCESS}




\title{
IMPROVING CONSTRUCTION PROJECT PERFORMANCE IN DEVELOPING COUNTRIES: CONTRACTOR APPROACH
}

\author{
SAMUEL A. ADEKUNLE ${ }^{1}$, CLINTON AIGBAVBOA ${ }^{1}$, and OBUKS A. EJOHWOMU ${ }^{2}$ \\ ${ }^{I}$ SARChl in Sustainable Construction Management and Leadership in the Built Environment, \\ Faculty of Engineering and the Built Environment, University of Johannesburg, \\ Johannesburg, RSA \\ ${ }^{2}$ School of Mechanical, Aerospace and Civil Engineering, The University of Manchester, \\ Manchester, UK
}

\begin{abstract}
Achieving project success remains the aim of every project sponsor. The sponsor engages different professionals in the built environment to this end. However, unforeseen factors modify agreed terms, causing delay and leading to loss of time and money. Delay causes an overrun of cost and time having a heavy financial burden on the client and other stakeholders involved in the project. Most times, the contractor is always the focus when this happens. At many other times, other stakeholders, who failed in their obligations, only surface after a study of the contract conditions is carried out. Thus, this study examines project performance in the construction industry in Nigeria, but from a contractor's perspective. The study adopts a survey research design. A total number of 75 questionnaires were administered to contractors, who were members of the Federation of Construction Industry and other private sector organizations, but 37 were successfully retrieved and analyzed. The result shows that to improve construction project performance in developing countries, the following issues need to be tackled: design and installation issues, payment issues and construction difficulties arising from incomplete designs by consultants. The study recommends, among other solutions, the incorporation of contractors from the project planning phase and adoption of BIM, which is presently not prevalent in the industry.
\end{abstract}

Keywords: Project governance, Project delay, Global south, Project success, Client satisfaction.

\section{INTRODUCTION}

Achieving project success in the construction industry has been a daunting task. The failure of a project to perform according to the planned objectives usually results in loss to parties involved. The project suffers from overruns in time and cost; this comes at a huge price to the parties. However, the construction team is most times helpless because the project is influenced by different factors; these can be internal or external factors. Thus, most times there are factors beyond the control of the project team (external factors). Musa et al. (2015) conducted a quantitative study that established the influence of external factors affecting the success of public housing projects. It was established that social and economic factors are important to the success of construction projects but then they are beyond the absolute control of the project team.

Furthermore, it is also worth mentioning that achieving project success is partly dependent on 
the articulation of the yardsticks to measure project success as it relates to the project at hand. According to Baccarini and Collins (2004), meeting the project objectives to the owner's taste is adjudged project success. Thus, a well-articulated project objective from inception is important because it will enable all stakeholders to be aware of the yardstick (if it will be based on the tripod yardstick (cost, time quality, benefits realization or other yardsticks).

To achieve the aim of this study, which is to establish the factors mitigating project performance from the contractor's perspective the manuscript is written in the following sequence: the article scanned literature to glean factors previously established in similar contexts to project performance, then the methodology and data gathering is presented, where respondents identified factors, acting as a clog in the wheel of project performance, but from the contractors' perspective.

\section{LITERATURE REVIEW}

The concept of project performance has been given different nomenclature in literature. It has been studied under different headings, these include project success, project performance, among others. Table 1 shows project performance in literature. Some other studies not presented in this table focused on critical success factors among other themes.

It has been established that factors affecting project performance are both external and internal. Wearne's (2014) study of the problems of success in project management practice opined that some factors affecting project performance (internal factors) could be solved at an organizational level. Thus, his findings were those that could be addressed by the project team. On the contrary, the findings of Musa et al. (2015) focused on external factors that affect project success and established that there were factors beyond the project team's control. Thus, there were factors that could not be totally controlled by the project team, as it required the input of the government or other external stakeholders. The external factors included social factors (Musa et al. 2015), corruption, political interference, change in government (Damoah et al. 2015) among others.

Although these studies have established factors affecting project performance, there exists a dearth in literature focusing on the activities of professionals in this regard. These previous studies focused on the factors (internal and external), and they also addressed the project manager as a success factor. This is because project management success as a form of project success is based on the achievement of project management objectives (Musa et al. 2015). However, the effect of other project team members' activities on project performance is yet to be captured in literature. The study, therefore, is embarked upon to achieve this using Nigeria as a case study in the developing countries context.

\section{RESEARCH METHODOLOGY}

This research investigates the factors hampering project performance through the lens of the contractor. The focus was basically to articulate project team activities that cause delay on construction projects in developing countries using Nigeria as a case study. A review of the literature was conducted to ascertain previous works. A study of previous studies revealed that project performance and project success, among other, were the nomenclature under which the project performance concept was conducted. The study adopted a survey research design. A total of 75 questionnaires were administered to contractors, who were members of the Federation of Construction Industry and other private sector organizations but 37 were successfully retrieved and analyzed. The respondents were specialized in civil construction, heavy engineering, and building construction projects. The contractors operated in the Lagos state area of Nigeria; they 
either had their operating offices in Lagos or on-going projects in the State. The respondents serviced different grades and types of clients in the construction industry.

Table 1. Studies in literature showing factors mitigating project performance (author compiled).

\begin{tabular}{ll}
\hline Author(s) & Variables \\
\hline Damoah et al. (2015) & Monitoring, Corruption, Political interference, Change in \\
& government, Bureaucracy, Lack of continuity, Fluctuation \\
& of prices, Planning, Delays in payment, Release of funds. \\
Rondinelli (1976) & Ineffective project planning and preparation, Faulty \\
& appraisal and selection processes, Defective project design, \\
& Problems in start-up and activation, Inadequate project \\
& execution, operation and supervision, Inadequate or \\
& ineffective external coordination of project activities, \\
& Deficiencies in diffusion and evaluation of project results \\
& and follow-up action \\
& Corruption, Lack of skills, absence of training and \\
& ignorance of project management knowledge, Lack of \\
& resources, failure to include the local community in \\
planning, project implementation, operations and no & arrangement for maintenance and operation of the project \\
deliverables
\end{tabular}

Idrus et al. (2011) Quality, cost, time

Wearne (2014)

Lindhard and Larsen (2016)

Iyer and Jha (2005)

Enshassi et al. (2009)
Project definition, resources, organization, time, cost, quality, safety, risk, contracts, change, inexperience

Consistent and correct project documents, external accumulation and sharing of experience, procedure for experience gathering, adequate use of knowledge sharing, well-functioning communication

Critical success factors

Project managers competence; top management support; project manager's coordinating and leadership skill; top management and owner involvement in the project; interaction between project participants, monitoring and feedback by project participants; owners competence; favorable climatic condition

Critical failure factors:

conflict among project participants; ignorance and lack of knowledge; indecisiveness; hostile socio-economic and climatic condition; the reluctance in timely decision; aggressive competition at the tender stage; short bid preparation time.

escalation of material prices, availability of resources as planned through project duration, average delay because of closures leading to materials shortage, availability of personnel with high experience and qualifications, quality of equipment and raw materials in the project, leadership skills for project managers.

\author{
Nomenclature

Causes of government \\ project failure in developing \\ countries - Focus on Ghana \\ Why Development Projects \\ Fail: problems of project \\ management in developing \\ countries
}

Causes of failure and abandonment of projects and project deliverables in Africa

Prioritizing Project

Performance Criteria within

Client Perspective

Evidence-Based Scope for

Reducing "Fire-Fighting" in

Project Management

Identifying the Key Process

Factors Affecting Project

Performance

Factors affecting cost performance: evidence from Indian construction projects

Factors affecting the performance of construction projects in the Gaza Strip 
From the data gathered, it was revealed that most building construction works were financed by individuals (private clients) and the federal government (public clients). $45.8 \%$ of the total population of the private client was the individually financed project. $12.5 \%$ of the private client was publicly quoted companies. This was followed by Property developers, limited company but not quoted and religious organization with $5 \%, 3 \%$, and $2 \%$, respectively. The remaining $14.7 \%$ shared equally by the other 7 types of private client. Also, in the public client cadre, it was evident that the federal government was the leading investor in the construction industry followed by the state government. It was apparent that the government was the major client of the construction industry and thus could determine the trend in the industry.

\section{FACTORS MITIGATING AGAINST PROJECT PERFORMANCE}

Respondents ranked the factors in Table 2 according to their proportional contribution to delay in project delivery. The ranking was done on a 6-point Likert scale $(1=$ None, $2=1-20 \%, 3=41 \%$ $60 \%, 4=61 \%-80 \%, 5=81 \%-100 \%$ ). The result is presented in the table below.

Table 2. Factors contributing to project delay.

\begin{tabular}{lll}
\hline Factors & Mean & $\begin{array}{l}\text { Ranking } \\
\text { index }\end{array}$ \\
\hline Payment issues & 4.13 & 2 \\
Constructional difficulties & 3.10 & 11 \\
Design issues by Architect & 3.50 & 4 \\
Design issues by structural engineers & 3.23 & 7 \\
Design issues by electrical engineers & 3.17 & 9 \\
Design issues by mechanical engineers & 5.21 & 1 \\
Quantity in the bill of quantities and cost /price issues & 3.15 & 10 \\
Variations due to design problems & 3.79 & 3 \\
Variations due to site or environmental difficulties & 3.48 & 5 \\
Variations due to regulatory/compliance with Government regulations & 3.27 & 6 \\
Fluctuations in materials & 3.21 & 8 \\
Fluctuations in labor & 2.81 & 12 \\
Labor and industrial relations issues & 2.50 & 16 \\
Disturbances emanating from parties external to the project & 2.52 & 15 \\
Compliance with contract documents & 2.56 & 14 \\
Buildability of design & 2.77 & 13 \\
\hline
\end{tabular}

From the result, Design issues on mechanical installation are ranked first and the one with the most contribution to project delays in the Nigerian construction industry. Design issues contribute between $81-100 \%$ of project delay in the Nigerian construction industry thus mitigating performance. The other factors are ranked in the following order; payment issues (contributes $61-80 \%$ of the project performance issues in the Nigerian construction industry), variations due to design problems (contributes $61-80 \%$ of the project performance issues in the Nigerian construction industry), design issues by Architect (contributes 41-60\% of the project performance issues in the Nigerian construction industry), variations due to site or environmental difficulties (contributes $41-60 \%$ of the project performance issues in the Nigerian construction industry), variations due to regulatory/compliance with government regulations (contributes 41$60 \%$ of the project performance issues in the Nigerian construction industry), design issues by structural engineers, fluctuations in materials, design issues by electrical engineers, quantity in the bill of quantities and cost /price issues, fluctuations in labor, buildability of design, compliance with contract documents, disturbances emanating from parties external to the project and labor and industrial relations issues. 
Thus, the most critical factors mitigating against project performance are design issues (Architectural, structural, electrical and mechanical), payment related issues and variations due to design problems. It is a common practice in the Nigerian construction industry that at the inception of projects, the Mechanical and electrical designs are always not firmed up. The quantity surveyors usually include a provisional sum in the BoQ for this purpose. This means that the $\mathrm{M}$ and $\mathrm{E}$ scope of the work wasn't fully defined at the beginning of the project. This births a lot of variation in the work, claims, and counterclaims result from this. Payment issues were established as another critical factor. The clients especially the government has a lot of bureaucratic bottlenecks when it comes to the honoring valuation certificates. Some private organizations too practice the system whereby many tables must approve the payment documents before the contractor is paid the amount certified. Delay in payments of certificates impacts negatively on the cashflow of the contractor and consequently the project performance among other effects (Amoako 2011).

Similar studies on improving construction project performance from the delay perspective have been conducted in the past. A study by Alaghbari et al. (2007) established the significant factors causing delay in the execution of projects in Malaysia; a study by Aibinu and Odeyinka (2006) on the causative factors causing project delay in Nigeria and Islam and Suhariadi (2018) study of Construction delays in privately funded large building projects in Bangladesh. Aibinu and Odeyinka (2006), and Alaghbari et al. (2007) established financial problems as top causes of project performance challenges however, Islam and Suhariadi (2018) established lack of experience, contractor selection and financial issues as the top three causes of project delays and extension a project challenge to project performance. This study is like the previous studies established payment/financial related issues as important to project performance however this study focuses mainly on the contractor perspective to project performance.

\section{CONCLUSION}

The study investigated how to improve project performance by articulating factors that cause project delay from the contractor's perspective. The knowledge and analysis of construction delay is important in the successful achievement (Islam and Suhariadi 2018). The challenges to project performance can be broadly classified as Design issues, payment/financial issues, variation/change orders, and fluctuation. The study thus advises that professionals fully adopt digitization (for instance BIM) in order to solve the design issue challenges. Prior to the commencement of the project, design will be completed and synchronized among the team thus reducing or totally eliminating change orders. Diligence and taking responsibility for their roles is also expected from professionals. It is worthy of note that some factors mitigating project performance as identified by this study are under the control of the project team. However, clients, especially government parastatals, need to work on the payment process in their organizations to ensure project performance.

\section{References}

Aibinu, A. A., and Odeyinka H. A., Construction Delays and Their Causative Factors in Nigeria, Journal of Construction Engineering and Management, 132(7), 667-777, doi:10.1061/(ASCE)07339364(2006)132:7(667), July, 2006.

Alaghbari, W. E., Kadir, M. R. A., and Salim, A., The Significant Factors Causing Delay of Building Construction Projects in Malaysia, Engineering, Construction and Architectural Management, 14(2), 192-206, doi:10.1108/09699980710731308, 2007.

Amoako, K. B., The Effect of Delayed Payment on Cash Flow Forecasting of Ghanaian Road Contractors, Master Thesis, Kwame Nkrumah University of Science and Technology, 2011. 
Baccarini, D., and Collins, A., The Concept of Project Success - What 150 Australian Project Managers Think., Australian Institute of Project Management (AIPM) Conference, 2004.

Damoah, C. A., Akwei, C., and Mouzughi, Y., Causes of Government Project Failure in Developing Countries - Focus on Ghana, BAM2015 Conference Proceedings, April, 2015.

Enshassi, A., Sherif, M., and Saleh, A., Factors Affecting the Performance of Construction Projects in the Gaza Strip, Journal of Civil Engineering and Management, 15(3), 269-280, doi:10.3846/13923730.2009.15.269-280, 2009.

Idrus, A., Sodangi, M., and Husin, M. H., Prioritizing Project Performance Criteria Within Client Perspective, Research Journal of Applied Sciences, Engineering and Technology, 3(10), 1142-1151, October, 2011.

Islam, M. S., and Suhariadi, B. T., Construction Delays in Privately Funded Large Building Projects in Bangladesh, Asian Journal of Civil Engineering, Springer, 19(4), 415-429, doi:10.1007/s42107-0180034-3, March, 2018.

Iyer, K. C., and Jha, K. N., Factors Affecting Cost Performance: Evidence from Indian Construction Projects, International Journal of Project Management, Elsevier, 23(4), 283-295, doi:10.1016/j.ijproman.2004.10.00, May, 2005.

Lindhard S., and Larsen, J. K.,. Identifying the Key Process Factors Affecting Project Performance, Engineering, Construction and Architectural Management, 23(5), 657-673, September, 2016.

Musa, M. M., Bin Amirudin, R., Sofield, T., and Mus, M. A. Influence of External Environmental Factors on The Success of Public Housing Projects in Developing Countries, Construction Economics and Building, 15(4), 30-44, 2015.

Okereke, C. O., Causes of Failure and Abandonment of Projects and Project Deliverables in Africa, PM World Journal, 6(1), 1-16, January, 2017.

Rondinelli, D. A., Why Development Projects Fail: Problems of Project Management in Developing Countries, Project Management Quarterly, Sage, 7(1), 10-15, doi:10.1177/097300520900500104, 1976.

Wearne, S., Evidence-Based Scope for Reducing 'Fire-Fighting' in Project Management, Project Management Journal, Sage, 45(1), 1-9, doi:10.1002/pmj2, 014. 